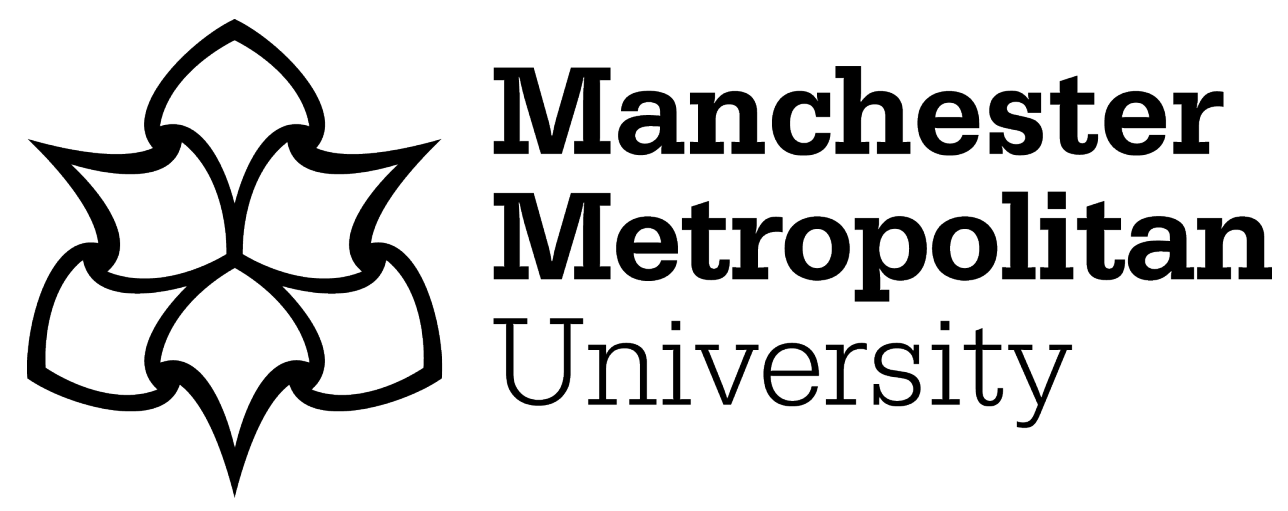

Luiselli, L and Fa, JE ORCID logoORCID: https://orcid.org/0000-0002-36118487 (2018) Ecology and conservation of West African forests: An introduction. Acta Oecologica, 94. ISSN 1146-609X

Downloaded from: https://e-space.mmu.ac.uk/623173/

Version: Accepted Version

Publisher: Elsevier

DOI: https://doi.org/10.1016/j.actao.2018.04.004

Usage rights: Creative Commons: Attribution-Noncommercial-No Derivative Works 4.0

Please cite the published version 


\section{Ecology and conservation of West African forests: An introduction}

Most of Africa's remaining rainforests are found in the Congo River basin on the Atlantic Ocean side of the continent, and only about $6 \%$ are distributed in West Africa (Mayaux et al., 2013). In the latter region, West African forests (also known as Guinean Forests) are distributed disproportionately along the coast, between Guinea-Bissau and Nigeria. West African forests are divided into two distinct sub-regions (Upper and Lower Guinea Forests), separated by the Dahomey Gap; the latter stretching from SW Ghana across to southern Benin, an area of savannah, dry forests and farmland.

West African forests contain an exceptional diversity of invertebrates, vascular plants and vertebrates (Oates, 1999; Mallon et al., 2015). However, forests in West Africa have been heavily fragmented due to the fast economic development of this part of the continent. The economic growth of countries in the region has been significantly greater than in other tropical areas across the world. For example, since the early 1980s, apart from a few isolated years of low performance, Nigeria averaged an annual growth rate of 10\%, and between 2012 and 2015 most other countries in the region grew at an annual rate of almost 7.0\% (World Bank Group Country Surveys data). Thus, given the exceptional biodiversity value of the region's forests and the relentless threats affecting this, the Guinean forests of West Africa must be considered among the highest priority ecological regions for ecologists and conservation biologists (Oates et al., 2004; Mallon et al., 2015).

Although the conservation of biodiversity in West African forests is considered of urgent importance, our knowledge of the distribution and status of many species is still poorly described. Moreover, the functional ecology of these ecosystems remains virtually unknown. Despite the fact that many studies are available on the ecology and conservation of West African forest animals and plants, significant gaps still exist in both our knowledge and understanding of West African forest biodiversity, (Luiselli et al., 2018a). In particular, there is a significant need for a much deeper understanding of species turnover patterns, together with work on the functional importance of biodiversity in these forest landscapes.

Our aims in this special issue of Acta Oecologica is to present a number of studies of multidisciplinary interest, that focus on the ecology and conservation of tropical forests of West Africa. We selected those manuscripts that would be of interest to general ecologists, by focusing on the analysis of patterns and processes of organisms and communities in forests and forest-derived habitats in West Africa, instead of merely describing the biodiversity of the region. Hence, we avoid the publication of species inventories and other more descriptive materials (though important, it is of probably of interest to only a minority of readers of an international journal of ecology such as Acta Oecologica), in this Special Issue we publish a wide range of subjects, from the issues affecting bushmeat hunting (Ávila et al., 2018; Luiselli et al., 2018b), the structure and evolution of fish communities (Amadi et al., 2018), the modeling of amphibian spatial baseline information (Penner et al., 2018), amphibian dispersal ecology (Penner and Rödel, 2018), as well as the heating effects of fire on soil seed density (Akinyemi et al., 2018). We also published the first ever review of the state of knowledge of the West African forests on the basis of a general bibliographic search (Luiselli et al., 2018a).

Last but not least, we would like to thank Dr Paula Campanello and the editorial board of Acta Oecologica for having allowed us to publish this Special Issue, all the authors who kindly submitted their valuable papers, and the many referees who reviewed the submitted drafts. Indeed, all papers were carefully peer-reviewed by at least two referees, and they went into 2 to 4 peer-review rounds. We really hope that our readers will be interested by our Special Issue, and that the various articles published in this volume will be widely cited in the next future.

\section{References}

Akinyemi, D.S., Oseni, S.R., Oke, S.O., 2018. Effect of heat on soil seedbank of three contrasting physiognomies in Shasha forest reserve, Southwestern Nigeria. Acta Oecol. https://doi.org/10.1016/j.actao.2018.03.009.

Amadi, N., Petrozzi, F., Akani, G.C., Dendi, D., Fakae, B.B., Luiselli, L., Pacini, N., 2018 Freshwater fishes of Lower Guinean forest streams: aquaculture heavily impacts the structure and diversity of communities. Acta Oecol. https://doi.org/10.1016/j.actao. 2017.07.001.

Ávila, E., Tagg, N., Willie, J., Mboh, D., Farfán, M.A., Vargas, J.M., Bonat, W.H., Dupain, J., Epanda, M.A., Luyten, I., Tedonzong, L., Peeters, M., Fa, J.E., 2018. Interpreting long-term trends in bushmeat harvest in southeast Cameroon. Acta Oecol. https:// doi.org/10.1016/j.actao.2017.09.007.

Luiselli, L., Dendi, D., Eniang, E.A., Fakae, B.B., Akani, G.C., Fa, J.E., 2018a. State of knowledge of research in the Guinean forests of West Africa region. Acta Oecol. https://doi.org/10.1016/j.actao.2017.08.006.

Luiselli, L., Hema, E.M., Segniagbeto, G.H., Ouattara, V., Eniang, E.A., Di Vittorio, M., Amadi, N., Parfait, G., Pacini, N., Akani, G.C., Sirima, D., Guenda, W., Fakae, B.B., Dendi, D., Fa, J.E., 2018b. Understanding the influence of non-wealth factors in determining bushmeat consumption: results from four West African countries. Acta Oecol. https://doi.org/10.1016/j.actao.2017.10.002.

Mallon, D.P., Hoffmann, M., Grainger, M.J., Hibert, F., van Vliet, N., McGowan, P.J.K., 2015. An IUCN situation analysis of terrestrial and freshwater fauna in West and central africa. In: Occasional Paper of the IUCN Species Survival Commission No. 54 IUCN, Gland, Switzerland and Cambridge, UK, pp. 162.

Mayaux, P., Pekel, J.-F., Desclée, B., Donnay, F., Lupi, A., Achard, F., Clerici, M., Bodart, C., Brink, A., Nasi, R., Belward, A., 2013. State and evolution of the African rainforests between 1990 and 2010. Phil Trans R Soc B 368 20120300. https://doi.org/ 10.1098/rstb.2012.0300.

Oates, J.F., 1999. Myth and Reality in the Rain Forest: How Conservation Strategies Are Failing in West Africa. University of California Press, Berkeley.

Oates, J.F., Bergl, R.A., Linder, J.M., 2004. Africa's Gulf of Guinea forests: biodiversità patterns and conservation priorities. Adv. Appl. Biodiv. Sci. 6, 1-91.

Penner, J., Augustin, M., Rödel, M.-O., 2018. Modelling the spatial baseline for amphibian conservation in West Africa. Acta Oecol. https://doi.org/10.1016/j.actao.2017.11.018. 
Penner, J., Rödel, M.-O., 2018. Keep it simple? Dispersal abilities can explain why species range sizes differ, the case study of West African amphibians. Acta Oecol. https:// doi.org/10.1016/j.actao.2017.11.011.

Luca Luiselli*

IDECC - Institute for Development, Ecology, Conservation and Cooperation,

Via G. Tomasi di Lampedusa 33, I-00144 Rome, Italy

Department of Applied and Environmental Biology, Rivers State University

of Science and Technology, P.M.B. 5080, Port Harcourt, Rivers State,

Nigeria
E-mail address: 1.luiselli@ideccngo.org

John E. Fa

Division of Biology and Conservation Ecology, School of Science and the Environment, Manchester Metropolitan University, Manchester M1 5GD,

Center for International Forestry Research (CIFOR), CIFOR Headquarters, Bogor 16115, Indonesia

E-mail address: jfa949@gmail.com 